\title{
SISTEM PENGUASAAN LAHAN DAN PENDAPATAN PETANI PADA WANATANI KEMIRI DI KECAMATAN CAMBA KABUPATEN MAROS
}

\author{
Land Tenure System and Farmer Income on Candle Nut Agroforestry in Camba District Maros Regency
}

Muh. Dassir

\begin{abstract}
Land tenure institution makkalice and mabbali on Timpuseng are not practice any more of the villagers. This causes many rabbing and decreases land holding (average $0.5 \mathrm{ha}$ ). While the farmers in Mariopulana village, still applying makkalice and mabbali, cause land holding still large enough (>1.5 ha). Land share cropper institution "teseng/ruma" and candle nut "mallolo" are still doing on family group, cause for helping. While in the institution of candle nut harvestig like makkampiri and makkalice, there are obtained pay system and there are not limited on the family group to get worker. The local knowledge of the land tenure in candle nut agroforestry can be basicly developed for tenure and land reform systems in social forestry. Through this system, they can maintain conservation and increase productivity of land without changing the forest status and functions. Those of landless farmers and land share priority for social forestry programs.
\end{abstract}

Key words: Land tenure, farmer income, candle nut agroforestry

\section{PENDAHULUAN}

Kompleks Hutan Bulusaraung merupakan hutan yang meliputi Kecamatan Cenrana, Camba, dan Mallawa, Kabupaten Maros, Propinsi Sulawesi Selatan. Luas wilayah hutan sebesar $515,0988 \mathrm{~km}^{2}$ atau 51.509,88 ha. Kompleks Hutan Bulusaraung mempunyai potensi wanatani dan kemiri rakyat yang terbilang luas di Sulawesi Selatan, yaitu seluas 31.331 ha dengan produksi 11.742 ton (BPS Maros, 2003). Kecamatan Camba merupakan salah satu kecamatan di Kompleks Pegunungan Bulusaraung yang mempunyai potensi wanatani. Luas Kecamatan Camba, yaitu 14.536 ha dengan potensi wanatani kemiri 12.556 ha.

Ada beberapa permasalahan riil dalam sistem wanatani di Kecamatan Camba sekarang ini, seperti: (1) kearifan lokal yang terdapat dalam sistem penguasaan lahan wanatani rakyat mengalami pergeseran nilai sejak penerapan teknologi (traktor, huller, bibit unggul) dan penerapan program pembangunan pedesaan oleh pemerintah, bahkan beberapa sistem distribusi hasil dan sistem penyakapan lahan telah tidak berfungsi lagi yang berimplikasi pada marginalisasi petani yang tidak mempunyai lahan, menurunnya rasa gotong royong dan kerjasama di antara petani, (2) sebagian besar petani mempunyai lahan lebih kecil dari satu hektar, sehingga tekanan terhadap kawasan hutan semakin meningkat untuk pembukaan areal pertanian baru akibat pertambahan jumlah penduduk, (3) terjadi konversi lahan dari hutan kemiri menjadi areal pertambangan, persawahan, peternakan, dan pertanian pangan tanpa memperhatikan daya dukung lahan, sehingga terjadi penurunan kualitas/ekologis lahan (Dassir, 2004).

Salah satu penyebab perubahan pranata penguasaan lahan dan timbulnya permasalahan penguasaan lahan dikarenakan perbandingan antara tanah-tenaga kerja telah turun begitu cepat disebabkan oleh angka pertambahan penduduk yang demikian cepat. Hal ini sejalan dengan yang terjadi di Pulau Jawa (Hayani dan Kikuchi, 1987). Untuk menopang pemenuhan kebutuhan pokok dilakukan usaha peningkatan produktifitas tanah dengan menerapkan pengembangan dan penyebaran teknologi benih-pupuk dan perluasan sistem irigasi, dan penyesuaian pranata-pranata yang mengatur pemakaian tanah dan penggunaan tenaga kerja.

Berdasarkan uraian di atas, beberapa pertanyaan penelitian yang muncul adalah: (1) bagaimana struktur hubungan antara tuan tanah dengan penyakap pada sistem penguasaan lahan yang terdapat pada wanatani kemiri rakyat, (2) bagaimana tingkat pendapatan antara pemilik penggarap, pemilik-penyakap, pemilik-penyewa lahan pada berbagai luasan lahan usaha tani yang dikelola, input teknologi (bibit dan sarana produksi), 
dan jumlah tenaga kerja yang digunakan, (3) sistem penguasaan lahan yang bagaimana yang memiliki kontribusi pendapatan yang lebih besar dan menimbulkan dampak kesempatan kerja dan saling menguntungkan di antara para pelaku pada sistem penguasaan lahan.

\section{BAHAN DAN METODE}

\section{Lokasi dan Sampel Penelitian}

Penelitian ini merupakan penelitian studi kasus di Kecamatan Camba Kabupaten Maros dengan mengambil sampel dua desa secara purposive sampling, yaitu Desa Timpuseng yang mempunyai karakteristik rasio luas lahan terhadap jumlah penduduk sebagian besar kurang dari satu hektar, mengelola lahan wanatani secara intensif dengan menggunakan teknologi padat modal dan mulai banyak petani menerapkan sistem agroforestry menggunakan bibit unggul. Sedang desa sampel lainnya, yaitu Desa Mariopulana yang mempunyai rasio luas lahan wanatani kemiri terhadap jumlah penduduk sebagian besar di atas satu hektar, mengelola lahan tidak intensif dengan input teknologi padat karya dan mengelola wanatani kemiri secara monokultur. Pemilihan responden pada setiap desa sampel dilakukan secara acak berlapis. Kriteria anggota masyarakat wanatani yang dijadikan dasar stratifikasi adalah: petani pemilik penggarap dan penyakap pada berbagai teknologi yang digunakan, luas lahan dan jenis tanaman yang diusahakan. Jumlah responden pada masing-masing desa sampel sebanyak 30 orang, sehingga total jumlah responden sebanyak 60 orang.

\section{Jenis dan Sumber Data}

Pengumpulan data dilakukan melalui pengamatan lapangan dan wawancara untuk merekam data:

1. Luas lahan yang digarap pemilik lahan dan luas lahan yang disakapkan.

2. Perubahan-perubahan dalam status pemilikan, penguasaan dan pemanfaatan tanah.

3. Pengenalan dan penanaman jenis-jenis tanaman baru, dan penerapan teknologi budidaya, teknologi pengolahan dan pemasaran hasil pada berbagai sistem penguasaan lahan.

4. Kesepakatan hak dan kewajiban (bagi hasil) di antara pelaku pada berbagai sistem penguasaan lahan.
5. Manfaat dan kerugian yang ditimbulkan dari sistem bagi hasil (hak dan kewajiban) pada sistem penguasaan lahan.

6. Biaya dan pendapatan petani pemilik penggarap, penyakap dan buruh tani pada berbagai luasan wanatani yang dikelola dan input teknologi yang digunakan.

\section{Analisis Data}

Untuk menjawab tujuan penelitian ini dilakukan analisis kualitatif dan analisis kuantitatif sebagai berikut:

1. Analisis kualitatif dilakukan terhadap data dan informasi yang dikumpulkan dari para informan, berupa kasus-kasus yang menggambarkan sistem penguasaan lahan pada wanatani kemiri dengan tahapan analisis data sebagai berikut:

a) Analisis deskriptif untuk menjelaskan struktur hubungan antara pemilik lahan wanatani kemiri rakyat dengan penyakap pada berbagai sistem penguasaan lahan yang terdapat pada wanatani kemiri rakyat, menyangkut kesepakatan hak (bagi hasil) dan kewajiban (tanggungan biaya) yang terjadi antar pemilik lahan dengan penyakap atau buruh tani.

b) Analisis tabulasi frekuensi untuk menjelaskan teknologi yang digunakan pada berbagai luas lahan wanatani yang dimiliki petani, luas lahan yang digarap oleh petani pemilik penggarap dan atau penyakap dan atau buruh tani, besarnya biaya produksi dan sistem bagi hasil pada berbagai sistem penguasaan lahan.

2. Analisis kuantitatif dilakukan untuk menjelaskan perbedaan pendapatan di antara pelaku yang terlibat sistem penguasaan lahan wanatani kemiri (petani pemilik penggarap, penyakap dan atau buruh tani). Tahapan analisis kuantitatif mencakup analisis biaya dan pendapatan petani dengan rumus:

$$
P=B P n-B T
$$

Dimana :

$\mathrm{P}=$ pendapatan petani

$B=$ harga jual berbagai hasil wanatani kemiri petani

$P n=$ jumlah produksi berbagai hasil wanatani kemiri petani

$\mathrm{BT}=$ biaya total wanatani kemiri rakyat 
Analisis ini ditujukan untuk mengetahui rasio pendapatan antara petani (pemilik) penggarap dengan petani penyakap dan buruh tani pada wanatani kemiri.

Hasil analisis kualitatif dan kuantitatif menjadi acuan dalam merumuskan perbaikan sistem penguasaan lahan wanatani kemiri yang dapat meningkatkan pendapatan petani dan menguntungkan di antara para pelaku penguasaan lahan kemiri rakyat.

\section{HASIL DAN PEMBAHASAN}

\section{Sistem Penguasaan Lahan}

Kelembagaan penguasaan lahan yang terdapat pada wanatani kemiri di Kecamatan Camba yang masih berlangsung dan diakui oleh masyarakat pada daerah tersebut, yaitu kelembagaan kepemilikan dan penyakapan lahan, kelernbagaan pengelolaan agroforestry kemiri, kelembagaan pasca panen, kelembagaan panen, secara garis besar diuraikan sebagai berikut:

\section{Kelembagaan Kepemilikan}

\section{a. Pemilik Penggarap}

Yang dimaksudkan dengan petani pernilik penggarap adalah petani yang mengelola sendiri areal wanatani kemirinya, dengan tanggung jawab atas pengelolaannya menjadi tanggung jawab sepenuhnya kepada pemilik lahannya. Petani pemilik penggarap mempunyai hak untuk memperoleh hasil yang diproduksi dari areal hutan yang dikelolanya serta mempertahankannya, termasuk dalam mengembangkannya, seperti penanaman, pemeliharaan, dan penebangan untuk tujuan peremajaan (mallolo).

\section{b. Teseng/ruma}

Kelembagaan pengelolaan hutan kemiri dengan sistem teseng/ruma adalah pemberian lahan hutan kepada orang lain untuk dikelola dengan cara bagi hasil. Masyarakat yang mengelola lahan kemiri rakyat disebut patteseng/paruma. Kegiatan teseng/ruma ini biasanya dilakukan dengan cara pemilik lahan memberikan kepada keluarga dekat atau orang lain yang dipercaya dengan sistem bagi hasil, besarnya bagi hasil yang berlaku umum adalah $2:$ I, di mana pemilik lahan mendapatkan bagian sebesar 2 bagian dan patteseng/paruma sebesar I bagian. Kelembagaan teseng/ruma ini biasanya terjadi pada pemilik lahan yang berdomisili di luar daerah di mana lahannya berada, sehingga tidak mampu mengurusi lahannya sendiri, maka untuk mengelola lahan tersebut diserahkan kepada orang lain.

Patteseng/paruma berkewajiban membersihkan dan menyulami tanarnan yang dianggap perlu. Untuk pengadaan bibit tanaman yang mudah diperoleh di lapangan dapat disediakan oleh paruma/paddare sedang jenis tanaman yang tidak tersedia di lapangan diusahakan oleh pemilik lahan. Pembayaran pajak atas lahan yang diusahakan oleb paddare/paruma merupakan tanggung jawab pemilik lahan.

Nilai sosial dari kelembagaan penguasaan lahan teseng pada wanatani kemiri adalah pemilik lahan memberikan peluang kepada masyarakat yang tidak memiliki lahan dan modaltapi mempunyai kemarnpuan untuk mengelola lahan. Di pihak lain terdapat masyarakat yang punya lahan tapi tidak mempunyai kemampuan untuk mengelola. Sehingga kelembagaan ini masih penting untuk diperhitungkan untuk pengembangan areal hutan di masa datang.

\section{c. Sanra / katenni}

Kelembagaan sanra/katenni adalah kelembagaan yang berlaku di masyarakat dalam pengelolaan lahan wanatani kemiri, di mana pemilik lahan menyerahkan lahannya untuk diusahakan oleh orang lain dengan ketentuan orang lain menyerahkan jaminan berupa uang kepada pemilik lahan. Adapun lahan tersebut dikembalikan kepada

\section{Tabel 1. Hak dan kewajiban pelaku kelembagaan penguasaan lahan teseng pada wanatani kemiri}

\begin{tabular}{ll}
\hline \multicolumn{1}{c}{ Uraian } & \multicolumn{1}{c}{ Hak dan kewajiban pelaku kelembagaan wanatani } \\
\hline Teseng & - pemilik lahan luas tidak didukung tenaga kerja memadai menyerahkan lahan yang \\
& - dimilikinya untuk dikelola oleh orang lain dengan sistem bagi hasil. \\
\hline Distribusi manfaat & - distem bagi hasil wanatani. \\
sumberdaya hutan & - peningkatan fungsi produksi lahah hutan. \\
& - penyerapan tenaga kerja. \\
& - sistem bagi hasil wanatani. \\
\hline
\end{tabular}


Tabel 2. Hak dan kewajiban pelaku kelembagaan penguasaan lahan sanra pada wanatani kemiri

\begin{tabular}{cl}
\hline Uraian & Hak dan kewajiban pelaku kelembagaan wanatani \\
\hline \multirow{3}{*}{ Sanra } & - penyerahan hak atas lahan milik untuk dikelola orang lain dengan jaminan berupa uang/emas. \\
& - Jaminan dikembalikan oleh passanra pada batas waktu kesepakatan. \\
& - passanra berhak memungut hasil wanatani pada lahan yang disanranya tetapi tidak berhak \\
& untuk mengambil kebijaksanaan pengelolaan seperti melakukan peremajaan tanpa \\
& sepengetahuan pemilik. \\
\hline Distribusi manfaat & - memanfaatkan modal yang menganggur di masyarakat untuk kegiatan produktif. \\
& - memberikan peluang kepada orang-orang yang tidak memiliki lahan atau lahannya masih \\
& sempit, tetapi memiliki modal. \\
\hline
\end{tabular}

pemiliknya selama beberapa waktu kemudian yang telah disepakati bersama. Pada kelembagaan sanra/katenni ini ada yang diistilahkan dengan passanra/pakkateni yaitu orang yang berhak mengelola lahan berdasarkan kesepakatan dengan pemilik lahan. Passanra/pakkateni berhak mengelola lahan tersebut dan seluruh hasilnya menjadi miliknya. Hasil baru dapat diperoleh pemilik lahan setelah hak sanra telah berakhir atau jaminan telah dikembalikan dari pemilik kepada passanra/ pakkatenni. Nilai jaminan yang akan dikembalikan ke pakkatenni/passanra setelah hak sanra berakhir berpatokan pada harga kemiri, beras atau harga emas pada saat pengembalian uang, sehingga uang yang dikembalikan oleh pemilik lahan tidak mutlak harus sama banyaknya dengan jumlah uang yang diambil dari pakkatenni/passanra.

Sanra/katenni ini biasanya terjadi pada saat masyarakat membutuhkan uang secara mendadak sehingga lahan yang dimiliki dapat dimanfaatkan untuk mendapatkan uang secara cepat tanpa harus menjual lahannya. Nilai sosial dan ekonomi yang terdapat pada kelembagaan penguasaan pada wanatani kemiri (Tabel 2) adalah memberikan peluang kepada masyarakat yang tidak memiliki lahan atau punya lahan sernpit tetapi mempunyai modal dan kemampuan untuk mengelola lahan, di pihak lain terdapat masyarakat yang memerlukan modal untuk memenuhi kebutuhan dalam melaksanakan aktivitas ekonomi lain. Dengan demikian maka masyarakat dalam melakukan aktivitasnya dapat saling menunjang dalam rangka pemenuhan kebutuhan sementara aktivitas lainnya masih dapat berjalan.

\section{Aspek Kelembagaan pada Pengelolaan Lahan dan Tegakan}

\section{a. Makkoko/Maddare}

Kelembagaan makkoko/maddare adalah kelembagaan yang berlaku di masyarakat dalam pengelolaan lahan hutan kemiri, di mana pemilik lahan menyerahkan lahannya untuk dikelola oleh orang lain selama kurun waktu kurang lebih tiga

Tabel 3. Hak dan kewajiban pelaku kelembagaan penguasaan lahan makkoko/maddare pada wanatani kemiri

\begin{tabular}{lll}
\hline \multirow{2}{*}{ Uraian } & \multicolumn{1}{c}{ Pemilik Lahan } & \multicolumn{1}{c}{ Pihak yang terlibat } \\
\cline { 2 - 3 } Hak & $\begin{array}{l}\text { Hak atas lahan kemiri dan vegetasi yang } \\
\text { tumbuh di atasnya setelah pakkoko } \\
\text { menyerahkan lahan kepadanya }\end{array}$ & $\begin{array}{l}\text { 1. Melakukan penanaman tanaman semusim di atas } \\
\text { areal lahan yang dikoko. }\end{array}$ \\
& & $\begin{array}{l}\text { 2. Memetik dan memungut hasil tanaman semusim } \\
\text { yang dilakukan selama proses makkoko } \\
\text { berlangsung. }\end{array}$ \\
\hline Kewajiban & 1. menyediakan input seperti bibit kemiri, & $\begin{array}{l}\text { 1. Melakukan persiapan lahan untuk penanaman } \\
\text { pohon kemiri. }\end{array}$ \\
& 2. $\begin{array}{l}\text { menanam pohon kemiri setelah lahan } \\
\text { dipersiapkan oleh pakkoko. }\end{array}$ & $\begin{array}{l}\text { 2. Memelihara dan merawat tanaman kemiri selama } \\
\text { proses makkoko berlangsung. }\end{array}$ \\
\hline Masalah & Terjadinya konflik lahan dengan pemerintah & $\begin{array}{l}\text { Konversi lahan kemiri ke komoditi lain, menyebabkan } \\
\text { terbatasnya lahan untuk kegiatan makkoko. }\end{array}$ \\
& sehingga proses peremajaan terhambat & \\
Distribusi & - Distribusi pemanfaatan lahan terhadap orang yang tidak punya lahan. \\
manfaat & - Peningkatan fungsi produksi lahan hutan. & \\
& - Penyerapan tenaga kerja. &
\end{tabular}


Tabel 4. Hak dan kewajiban pelaku kelembagaan panen makkampiri pada pengelolaan lahan wanatani kemiri

\begin{tabular}{|c|c|c|}
\hline \multirow[t]{2}{*}{ Uraian } & \multicolumn{2}{|c|}{ Pihak yang terlibat } \\
\hline & Pemilik Lahan & Pakkampiri \\
\hline Hak & $\begin{array}{l}\text { Mendapatkan dua bagian dari hasil } \\
\text { pemungutan kemiri. }\end{array}$ & $\begin{array}{l}\text { Mendapatkan satu bagian dari kemiri yang dipungut- } \\
\text { nya atau upah dalam bentuk uang dari pemilik. }\end{array}$ \\
\hline Kewajiban & $\begin{array}{l}\text { Menyerahkan satu bagian hasil kemirinya } \\
\text { kepada pakkampiri, atau membayar upah } \\
\text { kepada pakkampiri. }\end{array}$ & $\begin{array}{l}\text { 1. Melakukan pemungutan dan pengupasan buah } \\
\text { kemiri. } \\
\text { 2. Mengantar biji kemiri yang dipungut sampai ke } \\
\text { rumah pemilik kemiri. }\end{array}$ \\
\hline Masalah & $\begin{array}{l}\text { 1. Hilangnya nilai kegotong royongan yang } \\
\text { selama ini dianut masyarakat. } \\
\text { 2. Kebanyakan anggota keluarga bermigrasi } \\
\text { ke daerah lain. } \\
\text { 3. Produktifitas lahan menurun. }\end{array}$ & $\begin{array}{l}\text { 1. Meningkatnya kebutuhan hidup masyarakat. } \\
\text { 2. Menurunnya produktifitas lahan. } \\
\text { 3. Perubahan areal hutan kemiri menjadi komoditi } \\
\text { coklat. }\end{array}$ \\
\hline $\begin{array}{l}\text { Distribusi } \\
\text { manfaat }\end{array}$ & $\begin{array}{l}\text { - Distribusi hasil wanatani terhadap orang ya } \\
\text { - Penyerapan tenaga kerja. }\end{array}$ & tidak punya lahan wanatani. \\
\hline
\end{tabular}

tahun. Kegiatan yang dilakukan oleh paddare/ pakkoko adalah membuka lahan yang akan ditanami baik untuk tanaman baru maupun untuk peremajaan. Kemudian membersihkan lahan sampai siap tanam, selanjutnya menghubungi pemilik penanaman.Aturan yang biasa menjadi kesepakatan pada kelembagaan ini adalah paddare/pakkoko membersihkan lahan sampai siap tanam, pemilik menyiapkan bibit tanaman sekaligus menanami lahannya, pengelola (paddare/pakkoko) melaku-kan usaha tani tanaman semusim selama kurang lebih tiga tahun sampai tanaman semusim tidak bisa lagi diusahakan karena sudah tertutup dengan tanaman tahunan, seperti kemiri, jati, atau tanaman tahunan campuran lainnya seperti kopi dan coklat.

\section{b. Kelembagaan Panen}

Masyarakat dalam melaksanakan panen kemiri, terbagi atas beberapa tahap yaitu makkampiri, mabbali dan makkalice. Panen kemiri dengan cara makkampiri adalah kelernbagaan pemungutan kemiri yang dilakukan oleh pemilik lahan maupun orang lain pada tahap pemungutan pertama. Orang yang melakukan pemungutan kemiri disebut pakkampiri. Kegiatan makkampiri pada awalnya dilakukan dengan cara gotong-royong. Namun karena pertimbangan jumlah penduduk yang selalu meningkat dan kebutuhan juga semakin meningkat, kebiasaan masyarakat bergotong royong dalarn pemungutan kemiri ini sudah berubah menjadi sistem upah.

Kegiatan peningkatan kemiri dengan cara mabbali adalah kelembagaan pemungutan kemiri yang dilakukan oleh pemilik lahan atau dengan orang lain setelah pemungutan tahap pertama (makkampiri). Orang yang memungut kemiri disebut pabbali. Setelah kegiatan mabbali dilakukan, tanda larangan atau hompong dilepaskan oleh pemillik lahan sehingga masyarakat umum dapat melakukan pemungutan secara bebas pada lahan tersebut.

Tabel 5. Hak dan kewajiban pelaku kelembagaan panen pakkalice pada pengelolaan lahan wanatani kemiri

\begin{tabular}{lll}
\hline \multirow{2}{*}{ Uraian } & \multicolumn{2}{c}{ Pihak yang terlibat } \\
\cline { 2 - 3 } & \multicolumn{1}{c}{ Pemilik Lahan } & \multicolumn{1}{c}{ Pakkalice } \\
\hline Hak & $\begin{array}{l}\text { Mendapatkan perawatan dan pembersihan } \\
\text { lahan hutan kemiri yang dilakukan oleh } \\
\text { pakkalice }\end{array}$ & $\begin{array}{l}\text { Memungut dan berhak atas semua buah kemiri } \\
\text { yang dipungut }\end{array}$ \\
\hline Kewajiban & $\begin{array}{l}\text { 1. Menyerahkan lahan untuk dipungut buahnya } \\
\text { kepada masyarakat di sekitar }\end{array}$ & $\begin{array}{l}\text { Membersihkan rumput dan gulma pada areal hutan } \\
\text { kemiri yang dikalice. }\end{array}$ \\
& $\begin{array}{l}\text { 2. Mengumumkan kepada khalayak bahwa } \\
\text { waktu makkalice sudah dimulai. }\end{array}$ & \\
\hline Distribusi & - distribusi hasil wanatani terhadap orang yang tidak punya lahan & kemiri \\
manfaat & - penyerapan tenaga kerja & \\
\hline
\end{tabular}


Pelaksanaan panen kemiri dengan cara mabbali pada prinsipnya sama dengan cara makkampiri. Hal yang membedakan hanya waktunya, yaitu makkampiri merupakan panen kemiri pertama sedangkan mabbali merupakan kegiatan penen kedua.

Kelembagaan panen kemiri dengan cara makkalice yaitu kelembagaan panen kemiri dengan memberikan hak kepada orang untuk memungut kemiri tanpa harus meminta izin dari pemilik lahan. Orang memungut kemiri disebut pakkallice. Hasil panen kemiri yang diperoleh pakkalice menjadi milik seluruhnya tanpa harus menyerahkan sebagian kepada pemiliknya.

Kelembagaan makkalice mernpunyai nilal sosial. Nilai sosial yang melekat pada kelembagaan ini adalah adanya kesempatan memungut kemiri bagi orang yang tidak memiliki lahan atau mempunyai lahan sempit, sehingga mempunyai kesempatan untuk mempunyai kemiri tanpa melalui cara upah. Di samping itu, juga memberikan kesempatan kerja bagi yang tidak memiliki pekerjaan atau pekerjaannya kurang/ terbatas.

\section{Struktur Pembagian Hasil dan Tanggungan Biaya antara Pemilik Lahan dan Penyakap pada Wanatani Kemiri}

Struktur hubungan antara pemilik lahan dengan buruh wanatani kemiri, yaitu sebagian besar dalam bentuk mallolo ampiri, sedangkan sistem sanra dan teseng sudah tidak banyak yang melakukannya, disebabkan luasan lahan kemiri monokultur sudah sangat sedikit dan banyak terjadi konversi kemiri monokultur menjadi wanatani kemiri dengan coklat. Hal lain sehingga masyarakat tidak banyak yang melakukan penyakapan lahan disebabkan komoditas coklat pada wanatani kemiri merupakan salah satu sumber pendapatan harian dan sekaligus sebagai sumber pembelanjaan untuk tujuan konsumsi kehidupan sehari-hari, di samping dari sumber pendapatan di persawahan. Pada sistem mallolo kemiri melalui sistem berladang, maka semua hasil produksi menjadi milik buruh wanatani dengan lama kelola selama 3 tahun (Tabel 6).

Pendapatan penduduk yang tidak mempunyai lahan wanatani kemiri terjadi pada kelembagaan pengelolaan lahan, yaitu pada kelembagaan panen kemiri dengan menjadi buruh tani pada kegiatan makkamiri dan mabbali, atau melakukan panenan makkalice setelah panen raya kemiri pada lokasi/desa yang masih memberlakukan sistem kelembagaan tersebut. Kelembagaan makkalice dan mabbali pada Desa Timpuseng sudah tidak diberlakukan lagi oleh masyarakat melalui peraturan desa disebabkan seringnya terjadi pencurian kemiri dan juga disebabkan luas pemilikan lahan lahan masyarakat sudah sangat terbatas (rata-rata 0,5 ha). Sebaliknya pada petani di Desa Mariopulana, masyarakat masih memberlakukan sistem mabbali dan makkalice, dikarenakan lahan penduduk masih cukup luas, yaitu rata-rata lahan wanatani kemiri monokulturnya di atas 1,5 ha.

\section{Pendapatan Petani pada Wanatani Kemiri}

Tingkat pendapatan responden pada berbagai pola agroforestry ditentukan oleh luas lahan yang dimiliki petani dan pola tanam yang diterapkan pada setiap pola agroforestry kemiri. Hasil pengolahan data penelitian menunjukkan dari tiga pola agroforestry yang diterapkan oleh petani, rata-rata pendapatan dan rata-rata luas lahan berbeda-beda, sesuai pola tanam yang diterapkan responden. Rata-rata pendapatan dan rata-rata luas lahan pada berbagai pola agroforestry kemiri di Kecamatan Camba dapat dilihat pada Tabel 7 .

Hasil pada Tabel 7 menunjukkan bahwa pada pola agroforestry kemiri dengan coklat memberikan pendapatan bagi petani lebih tinggi dibanding

Tabel 7. Rata-rata pendapatan responden berdasarkan rata-rata luas lahan pada berbagai pola wanatani kemiri di Kecamatan Camba Kabupaten Maros

\begin{tabular}{crlcc}
\hline Lokasi studi & & \multicolumn{1}{c}{ Pola Agroforestry } & $\begin{array}{c}\text { Rata-rata } \\
\text { Pendapatan bersih } \\
\text { (Rp/tahun) }\end{array}$ & $\begin{array}{c}\text { Rata-rata Luas Lahan } \\
\text { (ha) }\end{array}$ \\
\hline Desa mariopulana & 1. & Pola monokultur kemiri & 974.166 & 1,5 \\
& 2. & Pola agroforestry kemiri (kemiri + coklat) & 4.730 .117 & 0,6 \\
& 3. & Pola ladang (mallolo) kemiri & 1.478 .928 & 0,5 \\
\hline Desa Timpuseng & 1. & Pola monokultur kemiri & 1.410 .000 & 0,5 \\
& 2. & Pola agroforestry kemiri kemiri + coklat) & 5.767 .667 & 0,3 \\
& 3. & Pola ladang (mallolo) kemiri & - & - \\
\hline
\end{tabular}


Tabel 8. Pendapatan petani pada berbagai luasan lahan dan pada berbagai pola wanatani kemiri

\begin{tabular}{ccccc}
\hline Lokasi studi & $\begin{array}{c}\text { Luas lahan } \\
\text { Agroforestry (ha) }\end{array}$ & \multicolumn{3}{c}{ Pendapatan petani pada berbagai pola wanatani (Rp/tahun) } \\
\cline { 3 - 5 } & & Monokultur Kemiri & $\begin{array}{c}\text { Agroforestry kemiri } \\
\text { (Kemiri +coklat) }\end{array}$ & ladang \\
\hline Desa Mariopulana & $\leq 0,5$ & 300.000 & 5.068 .000 & 1.478 .928 \\
& $1-0,5$ & 435.000 & 8.486 .250 & - \\
& $>1$ & 1.075 .040 & - & - \\
\hline \multirow{3}{*}{ Desa Timpuseng } & $\leq 0,5$ & 1.590 .000 & 4.562 .500 & - \\
& $1-0,5$ & - & 10.583 .333 & - \\
& $>1$ & - & - & - \\
\hline
\end{tabular}

dengan pola wanatani monokultur kemiri, baik pada Desa Mariopulana maupun pada Desa Timpuseng. Rata-rata pendapatan yang diperoleh petani tersebut merupakan pendapatan per tahun. Adanya perbedaan pendapatan rata-rata dari ketiga pola agroforestry, selain disebabkan karena perbedaan luas lahan juga karena adanya variasi teknologi pengolahan lahan dari setiap pola agroforestry, seperti di Desa Timpuseng sudah menggunakan sistem pemupukan pada wanatani kemiri monokultur maupun wanatani kemiri dengan coklat.

Pendapatan petani pada berbagai variasi luasan lahan pada kedua lokasi penelitian menunjukkan semakin luas lahan responden maka pendapatan petani juga semakin meningkat. Hal tersebut terjadi pada monokultur kemiri maupun pada agroforestry kemiri dengan coklat (Tabel 8).

\section{KESIMPULAN DAN SARAN}

\section{Kesimpulan}

1. Kelembagaan penyakapan lahan teseng/ruma dan mallolo makkampiri kebanyakan masih dilakukan dalam lingkup keluarga dengan maksud rasa saling tolong menolong, sedangkan pada kelembagaan panen hasil kemiri, seperti makkampiri dan makkalice sudah diberlakukan sistem upah dan sudah tidak terbatas pada keluarga terdekat yang dijadikan tenaga kerja.

2. Hasil pengamatan di lapang menunjukkan bahwa kelembagaan penguasaan lahan makkalice dan mabbali pada Desa Timpuseng sudah tidak diberlakukan lagi oleh masyarakat melalui peraturan desa disebabkan seringnya terjadi pencurian kemiri dan juga disebabkan luas pemilikan lahan lahan masyarakat sudah sangat terbatas (rata-rata 0,5 ha). Sedangkan pada petani di Desa Mariopulana, masyarakat masih memberlakukan sistem mabbali dan makkalice dikarenakan lahan penduduk masih luas, yaitu rata-rata lahan wanatani kemiri monokulturnya di atas 1,5 ha.

Terdapat perbedaan pendapatan antar petani wanatani monokultur dengan petani wanatani agroforestry, di mana dengan agroofrestry kemiri dengan coklat memberikan pendapatan yang lebih tinggi pada luasan yang sama dibanding monokultur kemiri.

\section{S a r a n}

1. Pertambahan penduduk tanpa dibarengi dengan ketersediaan lahan pertanian ataupun lahan wanatani akan menyebabkan semakin rawannya resiko perambahan kawasan hutan, sehingga perlu alternatif penyediaan ruang lahan wanatani melalui model perhutanan sosial.

2. Kearifan lokal sistem penguasaan lahan yang terdapat pada wanatani kemiri dapat dijadikan dasar bagi pengembangan sistem tenurial dan sistem land reform pada perhutanan sosial menyangkut kelembagaan pemberian hak kelola kawasan hutan dengan hak dan tanggungjawab yang dapat menjaga kelestarian lingkungan dan meningkatkan produktivitas lahan tanpa memberikan hak kepemilikan kawasan hutan dan merubah fungsi peruntukan hutan.

3. Petani yang tidak mempunyai lahan garapan wanatani atau lahan pertanian merupakan prioritas utama dalam penerapan perhutanan sosial dan dalam rangka mengatasi semakin terbatasnya penyediaan lapangan pekerjaan di pedesaan dari sistem penyakapan lahan oleh petani pemilik lahan

\section{DAFTAR PUSTAKA}

Baroes. J. 2004. Analisis Sistem Kelembagaan dalam Pengelolaan Hutan Kemiri Rakyat di 
Kecamatan Camba Kabupaten Maros. Tesis Pascasarjana Universitas Hasanuddin. Makassar (Tidak dipublikasikan).

BPS (Badan Pusat Statistik) Kabupaten Maros, 2003. Kecamatan Camba dalam Angka.

Dassir, M. 2004. Kelembagaan Hutan Rakyat di Sulawesi Selatan. Laporan Kerjasama Balai Pengolahan Daerah Aliran Sungai (BPDAS)
Jeneberang Walanai dengan Universitas Hasanuddin. Makassar (Tidak Dipublikasikan).

Hayami, Y dan M. Kikuchi. 1987. Dilema Ekonomi Desa: Suatu Pendekatan Ekonomi terhadap Perubahan Kelembagaan di Asia. Alih Bahasa: Sahara, D. Noer. Penerbit Yayasan Obor Indonesia. Jakarta.

Diterima : 24 November 2009

\section{Muh. Dassir}

Lab. Pemanenan dan Pembukaan Wilayah Hutan

Jurusan Kehutanan, Universitas Hasanuddin

Kampus Tamalanrea, Jl. Perintis Kemerdekaan Km. 10, Makassar 90245

Telp./Fax. 0411-585917. Indonesia 
Tabel 6. Struktur pembagian hasil dan tanggungan biaya antara pemilik lahan dan penyakap/buruh wanatani kemiri

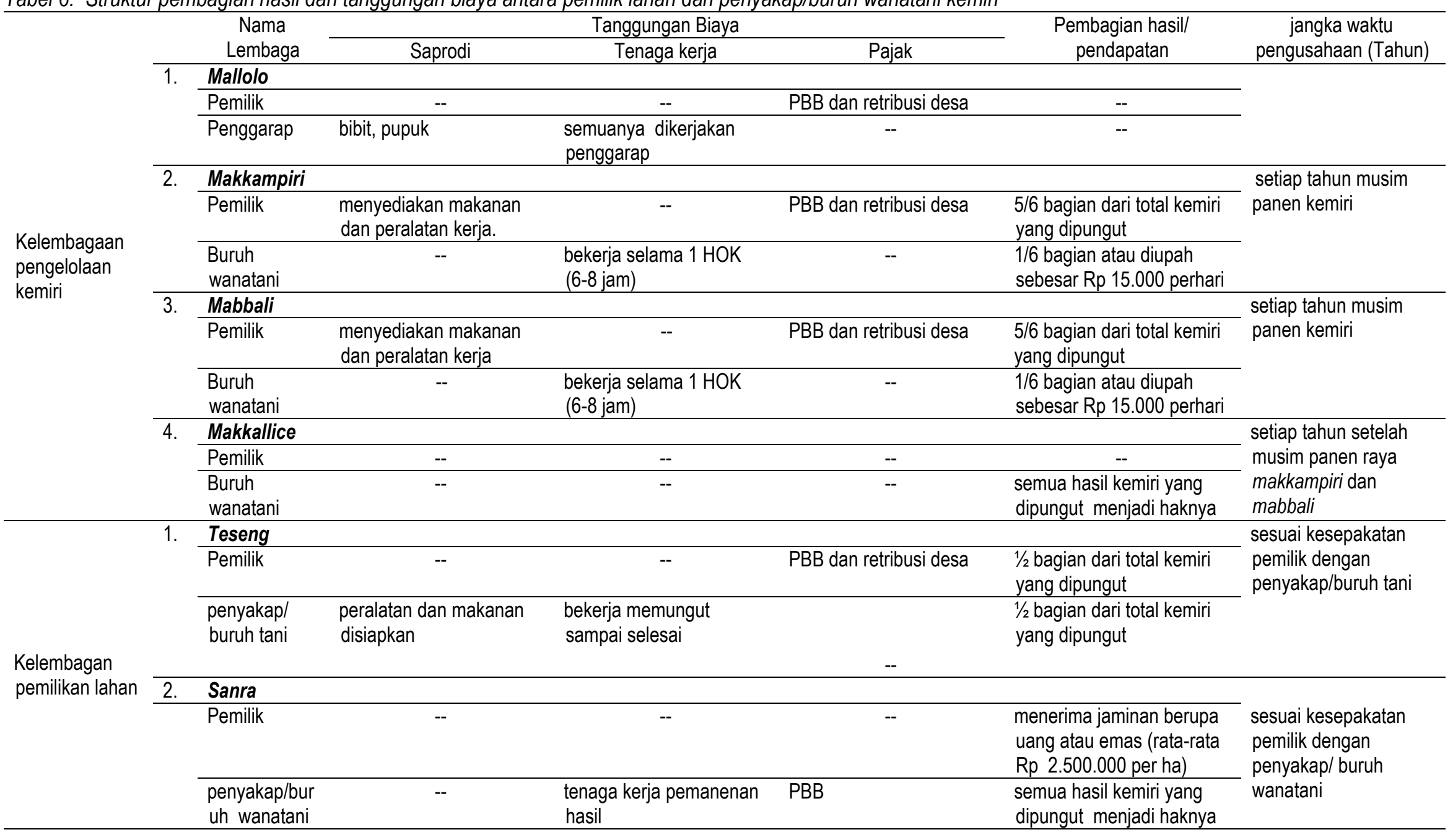

